\title{
Sexuality through the eyes of the elderly.
}

Yasmim da Silva Uchôa ${ }^{1}$

Dayara Carla Amaral da Costa'

Ivan Arnaldo Pamplona da Silva Junior'

Saulo de Tarso Saldanha Eremita de Silva'

Wiviane Maria Torres de Matos Freitas ${ }^{1}$

Soanne Chyara da Silva Soares'

\section{Abstract}

Objective: to identify the perception of elderly persons about sexuality. Methods: a quantitative, observational and analytical cross-sectional study was performed in an institution specializing in elderly care in Belém, in the state of Pará. A questionnaire, produced by the authors, was applied to 200 elderly persons, aiming to identify issues related to sexuality both in their youth and today, as well as stimulant strategies and sexuality inhibiting factors among the elderly, among other issues. Data was statistically analyzed through the G-Test for adherence. Results: The researched elderly had an average age of $72( \pm 5.92)$ years. The majority said they were not prepared for the beginning of sexual activity when young $(62.5 \%)$, and had little knowledge about sexually transmitted diseases or methods of preventing them (42.3\%). Today, the majority $(84 \%)$ did not understand the distinction between sexuality and sex, even though most $(69.5 \%)$ believed that they can stimulate their own sexuality. They also identified family (16.5\%) and religion (15.5\%) as inhibitory factors for their sexuality. A total of $28.5 \%$ of those interviewed reported having a sexual dysfunction and more than half (52.5\%) did not seek medical support. They believed that health professionals are prepared to deal with the issue, although such professionals are almost the last information source consulted $(17.5 \%)$ in relation to sexuality. Conclusion: many factors support the myth that older people are asexual: limited access to information from their youth to the present day, the physiological changes connected to aging itself, religious precepts and family oppression. However, further studies and actions directed at this population are important to promote the health of the elderly.
Keywords: Sexuality. Sexual heath. Elderly. Quality of life.

Centro Universitário do Pará (CESUPA), Curso de Fisioterapia. Belém, Pará, Brasil.

Correspondence

Soanne Chyara da Silva Soares

E-mail: soanne.chyara@gmail.com 


\section{INTRODUCTION}

Increasing life expectancy will result in an estimated trebling of the elderly population of Brazil over the next twenty years ${ }^{1-3}$. This increase is accompanied by greater attention being devoted to aging, a complex process that goes beyond the age gap ${ }^{4-6}$, involving aspects related to health, including sexuality as a variable that influences quality of life ${ }^{7}$. Bearing this in mind, the World Health Organization (WHO) defines quality of life as "an individual's perception of their position in life in the context of the culture and value systems in which they live and in relation to their goals, expectations, standards and concerns"8. It is essential to understand aging as a natural process and one that can be influenced by a comprehensive approach to health.

Quality of life encompasses the domain of the perception of the individual regarding sexuality, a complex variable due to its multidimensionality. Sexuality can be expressed through interaction with others and manifest itself in social relations through the body. It can also be described as a "way of existing in the world through Eros, which permeates daily human life"'. In this way, sexuality can be distinguished from sex which itself embodies only one form of the expression of human love ${ }^{7,10}$.

Aging does not mean becoming asexual, but sociocultural myths and taboos regarding sexuality in old age inhibit elderly persons from fully exercising this side of life, as the physiological alterations of aging, religious precepts, family oppression and individual aspects strengthen this social stigma $a^{11-13}$.

In terms of the natural physiological changes of aging, the Caderno de Atenção Básica (Basic Health Care Report) of the Ministry of Health describes the presence of erectile dysfunction in men and sexual dysfunction in women, with these physical changes causing a reduction in sexual libido and lubrication. Among other bodily alterations, flaccid skin, grey hairs, loss of teeth and chronic diseases may all negatively interfere with the expression of sexuality ${ }^{7,12,14}$.

In the religious context there are prohibitive aspects that impose a lack of sexuality on elderly persons, who could be considered as "sinners" and pejoratively regarded as vulgar and lacking in personal values in the case of women and "dirty old men" in the case of $\operatorname{men}^{13}$.

As for family and social oppression, a reversal of roles occurs in which elderly individuals lose control in the home and must adapt to this new reality, moving from active to passive subjects as they await the end of their lives. In addition, the children of such individuals often view sexuality in old age in a derogatory manner, seeing it as a sign of second childhood or dementia ${ }^{13,15}$.

With respect to widowhood, there are misconceptions that restrict sexuality, with religion, for example, impeding the continuity of romantic life when one partner dies, as it allows one marriage and considers family as the foundation of global society ${ }^{13}$. In addition, when they live without a partner, whether due to widowhood or other reasons, elderly women feel there is no space for a romantic life, experiencing only an unbroken silence. With this silence problems such as loneliness and somatic illnesses can also arise. As a result, women, who for most of their lives subjugate themselves to the needs of others, reach the apex of maturity, when they could be enjoying their freedom and autonomy, and find themselves bound by the judgments, stereotypes and prejudices imposed by their own families and society ${ }^{16}$. Because of the myths and taboos surrounding sexuality, it is not acknowledged that elderly persons still have sexual interests. One example of this is that the lack of campaigns to prevent sexually transmitted infections (STIs) aimed at this age group, as is sexual education and sexual health promotion. The consequences of this neglect are demonstrated by the increase in the occurrence of STIs among this population, for example Acquired Immunodeficiency Syndrome (AIDS), demonstrating the fragility of our understanding of the multidimensionality of human sexuality ${ }^{16-18}$.

The complexity of the theme explains the relevance of the present study, as does the fact that human sexuality is indispensable for the whole of life and in every part of the life cycle ${ }^{19}$. In an attempt to instigate reflection and discussion of the theme, this study aimed to identify the perceptions of elderly persons themselves regarding sexuality. 


\section{METHOD}

A quantitative, observational, analytical, crosssectional study was conducted in a public institution specializing in outpatient care for elderly persons in the metropolitan area of Belém, in the state of Pará. Elderly individuals aged 60 years or older, of both genders, who were registered at the unit and who agreed to participate in the study by signing a Free and Informed Consent Form (FICF), were included in the study, which was carried out between January and February 2014.

Individuals who had an objective clinical diagnosis of cognitive alterations and/or dementias, reported either by a companion or a medical or nursing professional, were subjectively excluded from the study, as were those who subjectively showed difficulty in understanding and/or provided incoherent responses during application of the questionnaire.

Sample calculation was performed with the aim of securing a sample of $10 \%$ of the elderly individuals who attended the institution and met the inclusion and exclusion criteria. The calculation was based on the number of elderly persons registered at the unit and individuals were selected in a nonprobabilistic manner "by convenience", based on the elderly people who attended consultations at the institution during the research period and who were invited to participate by the researchers.

The study was initially performed with 211 elderly individuals However, the final sample was reduced to 200 (146 women and 54 men) after the application of the inclusion and exclusion criteria, meeting the sample calculation requirements for this study.

For data collection, a questionnaire with questions written by the authors was used. This was developed following question calibration based on a pilot study conducted with elderly persons during supervised practices in primary care. Because of the elderly status of the population and with the aim of including individuals with different educational levels, the instrument was applied in an individualized and isolated manner in which the researchers read the questions and possible answers, allowing respondents to indicate the answer that best represented their knowledge regarding their experiences of sexuality during their youth and at the present time.

The instrument was composed of 16 questions that focused on: a) Youth of respondents: preparation for the initiation of sexual life, main sources of information, knowledge about STIs and their prevention; b) The present day: differences between sex and sexuality; level of stimulation, form of stimulation and factors that make it difficult to experience sexuality; regarding the association between aging and sexual dysfunctions, the presence of dysfunctions; and finally, how well professionals are prepared to address these issues with elderly persons.

For each item investigated, the possible responses varied between yes and no, with a graded scale of 'not at all/a little/somewhat/reasonably/very' with some exceptional items containing additional options pertinent to the question.

Descriptive analysis was used to identify and describe the data, and percentage values of the results were obtained and reported, as were measures of central tendency and dispersion, where relevant. The $G$ adhesion test was performed in order to analyze the significance of the results. This is a nonparametric test applied to samples with data measured on a nominal scale and arranged in two or more mutually exclusive categories. This test verified whether there was a significant difference between the expected and observed categorical variable of the evaluated sample. For the analysis, a value of $\mathrm{p}<0.05$ was allowed.

The present study was funded by the authors themselves and complied with the standards for research involving human subjects from Resolution 466/12 of the National Health Council. The study obtained the approval of the Municipal Health and Environment Department of Belém and was subsequently submitted and approved by the Research Ethics Committee, under number 439.844/13, while the individuals involved in the research signed a Free and Informed Consent Form. 


\section{RESULTS}

This study investigated 200 individuals, 54 (27\%) men and $146(73 \%)$ women, with a mean age of 72 $( \pm 5.92)$ years.

The responses to the questions regarding sexuality during the youth of the individuals revealed a significant difference in results, with the majority of respondents admitting that they had not felt prepared to begin their sexual life and describing friends (others) as their main sources of information. The responses also demonstrated a lack of available information about STIs and forms of prevention during youth (Table 1).
It was also noted that at the present time the majority $(84 \%)$ of the elderly persons were unable to distinguish sex from sexuality, although most believed that they stimulate their sexuality to a reasonable or high degree (Figure 1). Regarding factors that influence sexuality (Table 2), a gender analysis (data not shown in the table) highlighted certain stimuli such as shaving for men (67.96\%) and dressing up for women (42.46\%). In terms of inhibition factors, most elderly persons dismissed the existence of barriers, however a minority considered family, religion and lack of information aimed at their age group to be limiting factors.

Table 1. Perceptions of elderly persons regarding the initiation of their sexual life during their youth $(n=200)$. Belém, Pará, 2014.

\begin{tabular}{|c|c|c|}
\hline Variables & $\begin{array}{l}\text { Total } \\
\mathrm{n}(\%)\end{array}$ & p-value \\
\hline \multicolumn{3}{|c|}{ Did you feel prepared? } \\
\hline Not at all & $125(62.50)$ & \multirow{5}{*}{$\begin{array}{l}<0.0001 * \\
\text { (Test } G \text { ) }\end{array}$} \\
\hline A little & $14(7)$ & \\
\hline Somewhat & $25(12.50)$ & \\
\hline Reasonably & $22(11)$ & \\
\hline Very & $14(7)$ & \\
\hline \multicolumn{3}{|c|}{ Sources of information? ${ }^{1}$} \\
\hline Radio & $20(10)$ & \multirow[t]{6}{*}{$\mathrm{NA}$} \\
\hline Television & $13(6.50)$ & \\
\hline Newspapers & $10(5)$ & \\
\hline Parents & $24(12)$ & \\
\hline Others & $81(40.50)$ & \\
\hline No one & $69(34.50)$ & \\
\hline \multicolumn{3}{|c|}{ Knowledge of sexually transmitted infections } \\
\hline None & $82(41)$ & \multirow[t]{5}{*}{$<0.0001 *($ Test $\mathrm{G})$} \\
\hline Little & $40(20)$ & \\
\hline Average & $36(18)$ & \\
\hline Reasonable & $19(9.50)$ & \\
\hline Much & $23(11.50)$ & \\
\hline \multicolumn{3}{|c|}{ Information on prevention of sexually transmitted infections ${ }^{2}$} \\
\hline None & $50(42.37)$ & \multirow{5}{*}{$\begin{array}{l}<0.0001 * \\
\text { (Test } G)\end{array}$} \\
\hline Little & 25 (21.19) & \\
\hline Average & $11(9.32)$ & \\
\hline Reasonable & $20(16.95)$ & \\
\hline Much & $12(10.17)$ & \\
\hline
\end{tabular}

* Statistically significant difference $(\mathrm{p}<0.05)$; NA: Statistical test not applied; ${ }^{1}$ For this variable more than one answer could be obtained; ${ }^{2} \mathrm{Only}$ those who answered yes to the previous question. 


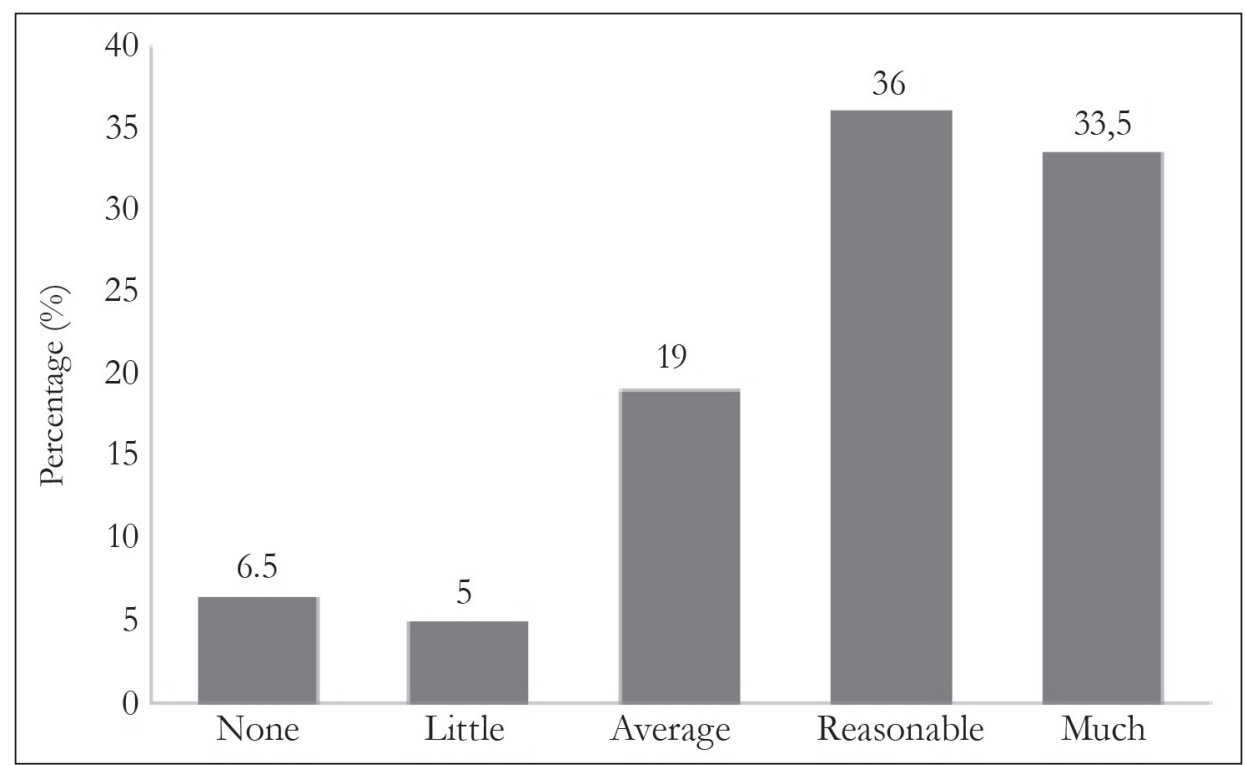

G Test, $p$-value $<0.0001$.

Figure 1. Perceptions of elderly persons regarding the stimulus of sexuality in their current life (N=200). Belém, Pará, 2014.

Table 2. Perception of elderly persons $(n=200)$ regarding the factors that influence sexuality in old age. Belém, Pará, 2014.

\begin{tabular}{ll}
\hline Difficulty / Problems & $\begin{array}{c}\text { Total } \\
\mathrm{n}(\%)\end{array}$ \\
\hline Forms of sexual stimulation $^{1}$ & $67(33.50)$ \\
Taking care of hair & $66(33)$ \\
Use of new perfume or aftershave & $90(45)$ \\
Dressing up & $40(20)$ \\
Dancing & $45(22.50)$ \\
Sexual act & $34(17)$ \\
Shaving & $50(25)$ \\
Dating & $64(32)$ \\
Meeting with friends & $30(15)$ \\
Others & $3(1.5)$ \\
None & \\
Factors that inhibit sexuality & \\
Society & $23(11.50)$ \\
Family & $33(16.50)$ \\
Religion & $31(15.50)$ \\
Lack of information & $30(15)$ \\
Changes to the body & $16(8)$ \\
Widowhood & $18(9)$ \\
Others & $7(3.50)$ \\
\hline
\end{tabular}

${ }^{1}$ For this variable more than one answer could be obtained. 
In relation to sexual dysfunctions during old age (Table 3), most of the elderly persons believed that the occurrence of these at this time of life is not normal, and only a minority reported suffering from any such dysfunction themselves. Of those who claimed to suffer from some sexual dysfunction, more than half had not sought guidance from a health professional. It is clear that there are still elderly individuals with sexual dysfunctions who do not seek care, even though most considered that health professionals are prepared to deal with sexuality in their patients. However, the main source of information regarding sexuality reported by the elderly persons was television, with health professionals being almost the least common response, demonstrating that despite being prepared professionals may not address this theme frequently enough.

Table 3. Perception of elderly persons regarding sexual dysfunction in old age ( $\mathrm{n}=200)$. Belém, Pará, 2014.

\begin{tabular}{lll}
\hline Variables & $\begin{array}{l}\text { Total } \\
\mathrm{n}(\%)\end{array}$ & $p$-value \\
\hline Consider it normal to have some dysfunction? & & \\
Yes & $63(31.50)$ & $<0.0001^{*}$ \\
No & $137(68.50)$ & (G Test) \\
\hline Do you have any dysfunction? & & \\
Yes & $57(28.50)$ & $<0,0001^{*}$ \\
No & $143(71.50)$ & (G Test) \\
\hline Sought professional health guidance ${ }^{1}$ & & \\
Yes & $27(47.37)$ & 0.6910 \\
No & $30(52.63)$ & (G Test) \\
\hline How prepared are health professionals? & & \\
Not at all & $18(9)$ & $<0.0001^{*}$ \\
A little & $16(8)$ & \\
Somewhat & $50(25)$ & \\
Reasonably & $59(29.50)$ & \\
Very & $57(28.50)$ & \\
\hline Sources of information ${ }^{2}$ & & \\
Family & $61(30.50)$ & \\
Friends & $51(25.50)$ & \\
Health professionals & $35(17.50)$ & \\
Church & $49(24.50)$ & \\
Television & $115(57.50)$ & \\
Magazines & $39(19.50)$ & \\
Internet & $12(6)$ & \\
Others & $22(11)$ & \\
\hline
\end{tabular}

* Statistically significant difference $(\mathrm{p}<0.05) ;{ }^{1}$ Only those who answered yes to the previous question; ${ }^{2}$ For this variable more than one answer could be obtained; NA: statistical test not applied. 


\section{DISCUSSION}

The global population is aging rapidly $y^{3,20}$ and society and elderly persons themselves still retain prejudices, myths and sociocultural taboos when it comes to sexuality, with resultant consequences and influences on the lives of old people $e^{1,11-13,21}$.

Sexuality is understood as "experience", a result of culture, history, fields of knowledge and subjectivity. It is not a static and definitive phenomenon and it comes with an uncountable range of forms of the expression and experience of pleasure ${ }^{22}$. Sexuality is related to love, tenderness and affection and is not just the sexual act itself, as erroneously believed by society ${ }^{7,10,21}$. In the present study, the elderly individuals did not know how to differentiate between sex and sexuality, restricting their definition to the sexual act and reproduction. This is a misconception, since all human beings are born as sexual subjects and enjoy sexuality differently in accord with each phase of their life, including the elderly stage ${ }^{7,10,21}$.

As a result of a historical process, sexuality is influenced by the actions of institutions such as school, church and the media. It has historically been viewed as impure, with sex, for example, being seen as related only to reproduction and not to pleasure ${ }^{23}$. Conceptions such as these can limit dialogue between parents and children and between health professionals and patients, making this an obscure topic, one which is experienced but not spoken of. Corroborating this idea, the present study observed that the elderly persons investigated had not felt prepared to begin their sexual life and did not discuss sex and sexuality with their parents or relatives, instead seeking information on the subject from "others". Qualitatively, these others were friends, because they were normally in the same age group and going through similar experiences. They represented a limited source of information, however.

Linked to this limited information during youth was the finding in the present study that most of the elderly persons had no knowledge about STIs at that time. In this respect, it is important to note that gonorrhea, for example, is among the oldest known human diseases ${ }^{24,25}$

The sexual education of the elderly persons was not created under the shadow of STIs and, therefore, the habit of condom use was not established in their early relations ${ }^{24,26}$. In the present study, the majority of elderly persons reported that during their youth they had no knowledge of STI prevention. In addition to not receiving this information during their youth, elderly persons must deal with the fact that present day STI prevention campaigns are directed almost exclusively at young people, suggesting that the increase in AIDS cases in this population (42.8\% between 1998 and 2010) is linked to a lack of information regarding sexuality ${ }^{16,18}$.

People have been unconsciously conditioned to believe that they should not or do not need to continue exercising their sexuality in old age, however its suspension or abandonment can accelerate the aging process with resultant negative effects on the health of elderly persons ${ }^{27,28}$. However, this study found that elderly persons believe that they stimulate their sexuality to a reasonable or great extent, mainly by dressing up and shaving, thus contributing to their well-being and increasing their disposition for life. Although society still conceives the exercise of sexuality as being for the young and does not sufficiently motivate elderly persons, they still seek to manifest their sexuality in other ways ${ }^{29}$.

The repression of sexuality in old age comes mainly from family, religion and society, with elderly persons having their pleasures suppressed and having to settle for a tedious future in order to fit in with the way of life imposed on them by society ${ }^{16}$. Due to role reversal, elderly persons lose their control of the home and need to readapt to this reality, moving from active subjects to passivity as they await death ${ }^{12,13}$. In this period, individuals can only assume the role of grandfather or grandmother. Their children ask them to look after their grandchildren in the expectation that they monitor them while performing activities such as knitting and watching television, enjoying their retirement ${ }^{15}$. These taboos and psychosocial 
blocks have repercussions in current society, for although most of the elderly persons in this research reported that there was no current factor limiting the exertion of their sexuality, there were a number who reported family, religion and a lack of information as such.

The aging process can lead to some physical changes, both in men and women, which induce sexual dysfunctions ${ }^{27}$. Biological factors limit sexual development, affecting desire, sexual functioning and, indirectly, sexual satisfaction. They cause hormonal changes, mainly taking the form of reductions in levels of testosterone for men and progesterone for women, with resultant changes in these relationships of these individuals with themselves and with society ${ }^{30}$. In this context, this study showed that approximately one third of the elderly individuals believed that it is normal to suffer from sexual dysfunctions, with slightly fewer reporting having a dysfunction themselves. In men, the principal dysfunction reported was sexual impotence, while in women it was a lack of sexual desire. This is complemented by the findings of the Basic Health Care Report of the Ministry of Health 14 , in which $64 \%$ of men reported erectile dysfunction and $65 \%$ of women reported reduced sexual libido and lubrication due to menopause. However, the sexual lives of both genders continue to be active ${ }^{12}$.

The majority of the elderly persons who reported suffering from some sexual dysfunction had not sought advice from a health professional, suggesting that there are still some professionals who are not prepared to discuss such matters with their patients. As the therapist-patient relationship is reciprocal in nature, it is up to health professionals to investigate the sexual history of their patients. Therefore, there appears to be some negligence in this area of health care, with care being focused solely on the complaint or illness of the individual, rather than on his or her health in its entirety ${ }^{7,26}$.

Due to this negligence, health professionals were cited by only one fifth of the elderly respondents in the present study as a main source of information on sexuality, with "television" instead being the most common information source. However, the media reinforces the idea that sexuality is related only to the bodies of the young, while elderly persons are portrayed as asexual. Considering the need for integral care, it is important that elderly persons intensively experience all the dimensions of life, that society welcomes them and that health professionals are aware of the important role they must play in promoting the health of human beings in all phases of life $^{31-33}$.

The results highlighted in the present study are not intended to conclude this discussion. The data should not be taken to be generally applicable, as the results and conclusions may not relate to other populations because of the sample used. Thus, the present study presupposes the reality of the issue within the context of public health and encourages the carrying out of further research. Given the large volume of details informally reported by respondents in the present study but not noted or considered due to being outside the scope of the study, it is advisable that new studies, especially involving qualitative research, be carried out with the aim of providing evidence regarding the views of elderly persons themselves on sexuality. In addition, it is necessary to incentivize the validation of quantitative instruments that deal not only with the sexual satisfaction/frequency of elderly persons, but also with aspects involved in individual sexuality. Further research on this theme is essential to foster the necessary socio-cultural changes and to assist with how professionals care for overall health.

\section{CONCLUSION}

In conclusion, the perceptions of elderly persons on sexuality have suffered from limitations, both during their youth and today. These limitations relate to various aspects of the knowledge of elderly persons, for example their inability to distinguish between sex and sexuality, which can reduce sexuality to the sexual act itself. This mistaken belief follows on from the youth of the individuals, where the beginning of their sexual lives was accompanied by insufficient information supplied by "friends", as demonstrated by the paucity of information regarding STIs and the preventive methods which they had access to. 
Currently, although some elderly persons believe that the presence of sexual dysfunctions in old age is "normal" and some suffer from such dysfunctions, they did not discuss the matter with health professionals for further clarification. On the other hand, even with so many inaccurate opinions, elderly individuals seek to stimulate their sexuality, mainly by dressing up, and recognize family, society and religion as factors that inhibit the exercise of their sexuality.

\section{REFERENCES}

1. Frugoli A, Magalhães Junior CAO. A sexualidade na terceira idade na percepção de um grupo de idosas e indicações para a educação sexual. Arq Ciências Saúde UNIPAR [Internet]. 2011[acesso em 10 abr. 2015];15(1):85-93. Disponível em: https://revistas. unipar.br/saude/article/view/3696/2398

2. Instituto Brasileiro de Geografia e Estatística. Dados sobre o envelhecimento no Brasil [Internet]. Brasília. DF: IBGE; 2012 [acesso em 30 jun. 2016]. Disponível em: http://www.sdh.gov. br/assuntos/pessoa-idosa/dados-estatisticos/ DadossobreoenvelhecimentonoBrasil.pdf.

3. Borges GM, Ervatt LR, Jardim AP. Mudança demográfica no Brasil no início do século XXI: subsídios para as projeções da população [Internet]. Rio de Janeiro: IBGE; 2015 [acesso em 30 jun. 2016]. Disponível em: https://biblioteca.ibge.gov.br/ visualizacao/livros/liv93322.pdf

4. Koopmans FF, Veiga ES, Costa BNGSC, Silva LA. A representação do sexo na terceira idade: uma contribuição para Saúde da Família. Cad Unisuam [Internet]. 2013 [acesso em 10 maio 2015];3(1):178-85. Disponível em: http://apl.unisuam.edu.br/revistas/ index.php/cadernosunisuam/article/view/414/372

5. Santos AFM, Assis M. Vulnerabilidade das idosas ao hiv/aids: despertar das políticas públicas e profissionais de saúde no contexto da atenção integral: revisão de literatura. Rev Bras Geriat Gerontol [Internet]. 2011[acesso em 20 jan. 2015];14(1):147-57. Disponível em: http://www.scielo.br/scielo.php?script=sci_arttext \&pid=S1809-98232011000100015

6. Brasil. Lei n 8.842, de 04 de janeiro de 1994. Dispõe sobre a política nacional do idoso, cria o Conselho Nacional do Idoso e dá outras providências. Diário Oficial da União. 05 jan 1994. Disponível em: http:// www.planalto.gov.br/ccivil_03/leis/18842.htm
The results of the present study do not conclude the discussion regarding the topic of sexuality among elderly persons, instead highlighting the need for the study of several aspects inherent to sexuality, such as: of the degree of satisfaction of elderly persons, the level of training for professionals and even the perceptions of society regarding the subject. It is precisely through such studies that the myths and taboos surrounding the issue will be broken, granting dignity to human beings from birth to old age.

7. Bernardo R, Cortina I. Sexualidade na terceira idade. Rev Enferm Unisa [Internet]. 2012 [acesso em 20 mar. 2016];13(1):74-8. Disponível em: https:// www.unisa.br/graduacao/biologicas/enfer/revista/ arquivos/2012-1-13.pdf

8. World Health Organization, Department of Mental Health. The World Health Organization Quality of Life [Internet]. Genebra: WHO; 2012 [acesso em 01 jul. 2016]. Disponível em: https://www.who.int/ mental_health/publications/whoqol/en/

9. Labronici LM, Trentini M. Eros proporcionando a compreensão da sexualidade das enfermeiras. Cogitare Enferm [Internet]. 2001 [acesso em 11 set. 2015];6(1):67-74. Disponível em: https://repositorio. ufsc.br/handle/123456789/82515

10. Silva LAN, Oliveira AAV. Idosos, Sexualidade e doenças sexualmente transmissíveis: revisão integrativa da literatura. Rev Divulgação Científica Sena Aires [Internet]. 2013 [acesso em $20 \mathrm{fev}$. 2016];2(2):197-206. Disponível em: http:// revistafacesa.senaaires.com.br/index.php/revisa/ article/view/106/58

11. Moraes KM, Vasconcelos DP, Silva ASR, Silva RCC, Santiago LMM, Freitas CASL. Companheirismo e sexualidade de casais na melhor idade: cuidando do casal idoso. Rev Bras Geriatr Gerontol [Internet]. 2011 [acesso em 10 abr. 2015];14(4):787-98. Disponível em: http://www.scielo.br/pdf/rbgg/ v14n4/a18v14n4.pdf

12. OKUNO MFP, Gomes AC, Meazzini L, Scherrer Júnior G, Belasco Junior D, Belasco AGS. Qualidade de vida de pacientes idosos vivendo com HIV/AIDS. Cad Saúde Pública [Internet]. 2014 [acesso em 23 abr. 2015];30(7):1551-9. Disponível em: http://www.scielo. br/pdf/csp/v30n7/0102-311X-csp-30-7-1551.pdf 
13. Torres EM. A viuvez na vida dos idosos [Dissertação na Internet]. Salvador: Universidade Federal da Bahia; 2006 [acesso em 23 abr. 2015] Disponível em: https://repositorio.ufba.br/ri/bitstream/ri/12511/1/ DISSER_PGENF_188_ELIS\%C3\%82NGELA.pdf

14. Brasil. Ministério da Saúde. Envelhecimento e saúde da pessoa idosa [Internet]. Brasília, DF: Ministério da Saúde; 2006 [acesso em 10 abr. 2015]. Disponível em: http://bvsms.saude.gov.br/bvs/publicacoes/ abcad19.pdf

15. Neto FAD, Santana MAS, Lucena ECL, Soares MCS, Lima KMM. Sexualidade na terceira idade: compreensão e percepção do idoso, família e sociedade. Rev Univ Vale Rio Verde [Internet]. 2014 [acesso em 23 abr. 2015];12(1):317-6. Disponível em: http://revistas.unincor.br/index.php/revistaunincor/ article/view/1385

16. Souza M, Marcon SS, Bueno SMV, Carrera L, Baldissera VDA. A vivência da sexualidade por idosas viúvas e suas percepções quanto à opinião dos familiares a respeito. Saúde Soc [Internet]. 2015 [acesso em 20 jun. 2016];24(3):936-44. Disponível em: http://www.scielo.br/pdf/sausoc/v24n3/0104-1290sausoc-24-03-00936.pdf

17. Maschio MBM, Balbino AP, Souza PFR, Kalinke LP. Sexualidade na terceira idade: medidas de prevenção para doenças sexualmente transmissíveis e AIDS. Rev Gaúch Enferm [Internet]. 2011 [acesso em 15 abr. 2015];32(3):583-9. Disponível em: http://www.scielo. br/scielo.php?pid=S198314472011000300021\&script =sci_arttext

18. World Health Organization. A wealth of information on global public health [Internet]. Genebra: WHO; 2014 [acesso em 30 jun. 2016]. Disponível em http:// apps.who.int/iris/bitstream/10665/112739/1/WHO_ HIS_HSI_14.1_eng.pdf?ua=1

19. Mallaguti W, Bergo AMA. Abordagem interdisciplinar do idoso. Rio de Janeiro: Rubio; 2010.

20. Organização Mundial da Saúde. Guia Global: Cidade Amiga do Idoso [Internet]. Genebra: WHO; 2008 [acesso em 30 jun. 2016.] Disponível em http://www. who.int/ageing/GuiaAFCPortuguese.pdf

21. Alencar DL, Marques APO, Leal MCC, Vieira JCM. Fatores que interferem na sexualidade de idosos: uma revisão integrativa. Ciênc Saúde Coletiva [Internet]. 2014 [acesso em 01 jul. 2016];19(8):353342. Disponível em: http://www.scielosp.org/pdf/csc/ v19n8/1413-8123-csc-19-08-03533.pdf
22. Foucault M. História da sexualidade: a vontade de saber. 13. ed. Rio de Janeiro: Edições Graal; 1988.

23. Louro GL. O corpo educado: pedagogias da sexualidade. 3. ed. Belo Horizonte: Autêntica Editora; 2007.

24. Rocha FCV, Melo SBS, Chaves NN, Silva Júnior FJG, Sousa CMM, Alves ELM. Prevenção das doenças sexualmente transmissíveis: a visão de um grupo da terceira idade. Rev Pesqui Cuid Fundam [Internet]. 2011 [acesso em 27 mar. 2015];3(5 n. esp):63-9.

Disponível em: http://www.seer.unirio.br/index.php/ cuidadofundamental/article/view/1935

25. Penna GO, Hajjar LA, Braz TM. Gonorréia. Rev Soc Bras Med Trop [Internet]. 2000 [acesso em 05 jul. 2016];33(5):451-64.Disponível em: http://www.scielo. $\mathrm{br} / \mathrm{pdf} / \mathrm{rsbmt} / \mathrm{v} 33 \mathrm{n} 5 / 3125 . \mathrm{pdf}$

26. Batista AF, Marques APO, Leal MCC, Marino GJ, Melo HMA. Idosos: associação entre o conhecimento da AIDS, atividade sexual e condições sociodemográficas. Rev Bras Geriatr Gerontol [Internet]. 2011 [acesso em 13 jun. 2016];14(1):39-48. Disponível em: http://www. scielo.br/scielo.php?script=sci_arttext\&pid =S1809-98232011000100005

27. Silva, VXL, Marques APO, Lira J, Medrado M, Leal MCC, Raposo MCF. Satisfação sexual entre homens idosos usuários da atenção primária. Saúde Soc [Internet]. 2012 [acesso em 28 jun. 2016];21(1):171-80. Disponível emhttp://www.revistas.usp.br/sausoc/ article/view/29828/31714

28. Araújo SL, Zazula R. Sexualidade na terceira idade e terapia comportamental: revisão integrativa. Rev Bras Ciênc Envelhec Hum [Internet]. 2015 [acesso em 15 jun. 2016];12(2):172-82. Disponível em: http://seer. upf.br/index.php/rbceh/article/viewFile/5054/pdf

29. Bastos CC, Closs VE, Pereira AMVB, Batista C, Idalêncio FA, De Carli GA, et al. Importância atribuída ao sexo por idosos do município de Porto Alegre e associação com a autopercepção de saúde e o sentimento de felicidade. Rev Bras Geriatr Gerontol [Internet]. 2012 [acesso em 13 jun. 2016];15(1):87-95. Disponível em: http://dx.doi.org/10.1590/S180998232012000100010.

30. Wylie KR, Wood A, MCMANUS R. Sexuality and old age. Bundesgesundheitsblatt Gesundheitsforschung Gesundheitsschutz [Internet]. 2013 [acesso em 13 jun. 2016];56(2):223-30. Disponível em: https://www.ncbi. nlm.nih.gov/pubmed/23361207 
31. Botacci LFG. A construção social do sexo: alguns aspectos a considerar sobre a terceira idade. Trilhas Hist [Internet]. 2011 [acesso em 1 jul. 2016];1(1):14558. Disponível em: http://www.trilhasdahistoria. ufms.br/index.php/RevTH/article/view/350/pdf_10

32. Goldenberg M. Mulheres e envelhecimento na cultura brasileira. Cad Espaç Fem [Internet]. 2012 [acesso em 01 jul. 2016];25(2):46-56. Disponível em: http://www.seer.ufu.br/index.php/neguem/article/ view/21803/11965

Received: December 3, 2015

Reviewed: July 11, 2016

Accepted: November 7, /2016
33. Queiroz MAC, Lourenço RME, Coelho MMF, Miranda KCL, Barbosa RGB, Bezerra STF.

Representações sociais da sexualidade entre idosos. Rev Bras Enferm [Internet]. 2015 [acesso em 01 jul. 2016];68(4):662-7. Disponível em: www.scielo.br/pdf/ reben/v68n4/0034-7167-reben-68-04-0662.pdf 